\title{
RESEARCH AND TRADITION
}

Article received on $20^{\text {th }}$ March 2015

Article accepted on $12^{\text {th }}$ May 2015

UDC: 782.6

Jernej Weiss*

University of Ljubljana

Academy of Music

\section{ANTON FOERSTER'S GORENJSKI SLAVČEK: SLOVENIA'S FIRST NATIONAL OPERA?}

\begin{abstract}
Particularly at the end of the $19^{\text {th }}$ century, the constantly rising Slovenian national consciousness saw a great opportunity in theatre and opera, which became the centre of a national movement with which the young bourgeoisie identified. Gorenjski slavček (The Nightingale of Upper Carniola), an operetta by Anton Foerster, one of the leading Czech composers in Slovenia, was staged for the first time in Ljubljana in 1872 by the Dramatic Society and, after being adapted for the operatic stage in 1896, soon became the most popular and most frequently performed Slovenian stage-music composition. This warm reception led the Slovenian bourgeoisie of that time to believe that Gorenjski slavček could become the first Slovenian national opera.

Considering the overall image of Foerster's Gorenjski slavček in music history and the social and political issues of the time when it was written, the composition seems more like a warm and rather undemanding expression of intimacy than a national opera in the true sense of the word. For adequate aesthetic consideration, it is therefore necessary to
\end{abstract}

* Author contact information: Jernej.Weiss@ff.uni-lj.sis 
understand the opera primarily as a document of its time and the circumstances of its origin, in all its simplicity and naivety. Although from today's perspective the opera does not attain an above-average standard and so could not be successful on foreign opera stages, it is still interesting because of the specific role it played as a national agitator in the period discussed.

Keywords: Anton Foester, Gorenjski slavček, opereta, opera, remakes, Hilarion Benišek

Anton Foerster is undoubtedly one of those Czech composers who contributed most importantly to both sacral and secular musical creativity in Slovenia in the second half of the $19^{\text {th }}$ and early $20^{\text {th }}$ centuries. When evaluating his composing work, first of all it seems necessary to stress that after his arrival in Ljubljana in 1867, Foerster encountered, in an institutional sense, more or less chaotic circumstances. Namely, the singing choirs - both the church and secular ones - as well as the majority of other performing institutions, were on an extremely unenviable level as regards quality. Foerster thus had to adapt his creative poetics, which in the Czech lands had been predominantly marked by Smetana's, Dvořák's and other influences, to the existing circumstances in Slovenia. Nevertheless, certain compositions from his initial creative period transcend this narrow creative frame and reveal a composer who was able to demonstrate, in some of his compositions, all of his comparatively rich compositionaltechnical knowledge.

\section{Gorenjski slavček - the operetta}

Foerster's musical stage creativity was in every sense influenced by the establishment of the Dramatic Society in Ljubljana in 1867, which was the first to begin regularly staging drama plays and musical performances in the Slovenian language. ${ }^{1}$ In particular, the operetta was very popular in that period and could frequently be found on the repertoire of the old German Provincial Theatre, where, from the 1870/71 season onward, the Dramatic Society held guest performances three times a week. Soon after its establishment, the Society opened its own acting and singing school in order to acquire new performers. In addition to the initial drama plays, a growing number of plays with songs, operettas, as well as excerpts from operas began to appear on the Society's repertoire. Foer-

\footnotetext{
${ }^{1}$ Musical performances had occasionally been staged in Slovenia before this period by the Ljubljana Reading Society. Among others, the Society premièred the operettas Tičnik (The Aviary) by Benjamin Ipavec (4 February 1866) and Jamska Ivanka (Ivanka of the Jama Castle) by Miroslav Vilhar (30 March 1871). Henrik Neubauer, Opereta v Sloveniji: Zgodovinski pregled, Ljubljana, Glasbena matica Ljubljana, 2008, 15, 19.
} 
Weiss, J.: Anton Foerster's Gorenjski slavček: Slovenia's first national opera?

ster was certainly well-acquainted with these works, as he had been active in the Dramatic Society as the conductor and accompanist since its establishment. He proved his conducting abilities on 19 March 1869 during the repeat performance of the operetta Tičnik (The Aviary) by Benjamin Ipavec. But his real moment of glory came on 27 April 1872 with the première of his operetta Gorenjski slavček (The Nightingale of Upper Carniola).

As early as 1869 , the Carniolan Provincial Committee announced a public competition for "an original Slovenian drama and musical theatre formation". ${ }^{2}$ Its intention was not only to encourage new Slovenian musical-stage creativity, but primarily to accelerate the establishment of the first Slovenian national theatre. Just how topical the last-mentioned goal was is evident in the reply of the Dramatic Society's Committee dated 5 July 1869:

After careful consideration of the above-mentioned issues, the Committee has set as its guiding principle the fact that in this matter the Society must always remain focused on its principal goal and final objective, that is, the establishment of a permanent national theatre in Ljubljana, and that it must utilise all the best means available to enhance the achievement of this objective. ${ }^{3}$

At first, Foerster was not intent on entering the mentioned public competition because of his heavy workload, but was nevertheless persuaded to do so by his wife Patronila, ${ }^{4}$ who wanted to at least slightly improve her family's modest finances. It had come to her knowledge that the poetess, writer, translator and great patriot, Lujiza Pesjak, was preparing a libretto that she felt might be suitable for her husband's first musical-stage work. Foerster joined forces with the librettist, and already in 1869 began to set the libretto to music, after having previously made some minor changes in it, himself. While composing, he was well aware of the very modest performing abilities available to the Dramatic Society, at that time. Initially, his Slavček comprised only individual music pieces performed in between spoken, unconnected texts. There were altogether 13 of these: the overture, Franjo's aria in D major, Minka's aria in B major, Minka's and Franjo's duet in A major, Minka's aria in G major, Chansonette's aria in E-flat major, the quintet of Minka, Ninon, Franjo, Lovro and Chansonette in E minor, the choir of villagers in D major, ensemble (Rajdelj, Chansonette, Ninon and chorus) in E major, the chorus of villagers Ave Maria in F major, the toast

\footnotetext{
${ }^{2}$ Anton Trstenjak, Slovensko gledališče: zgodovina gledaliških predstav in dramatične književnosti slovenske, Ljubljana, Dramatično društvo, 1892, 58.

${ }^{3}$ Ibid.

${ }^{4}$ Born Vesely (1847-1941), whom he married in 1863. Patronila always stood by her husband and was his strong support. It is owing to her that he wrote the Klavirska šola (Piano school), and ultimately dedicated Gorenjski slavček to her.
} 
of Lovro with choir in A major, Minka's aria in E major, and the final part with a reprise of the toast in A major. ${ }^{5}$

Due to the insufficient response - Slovenian composers of musical-stage works were lacking - the initial deadline for the acceptance of compositions in the competition was slightly extended. For an additional six more months after the end of 1870, that is, until the end of June $1871 .{ }^{6}$ However, besides the operetta Prepir o ženitvi (Quarrel about Marriage) by Anton Hribar, a today almost entirely unknown teacher from Vipava, organist and choirmaster of the Reading Society choir in Gorica, with libretto by Slovenian poet and priest Jurij Fabrijan, Foerster's work was the only musical-stage work received in the competition. ${ }^{7}$

Both musical-stage works were sent, together with a letter of the Carniolan Provincial Committee dated 21 September 1871, to the evaluation committee in Prague, whose members were Foerster's former teachers from Prague: Ljudevit Procházka, Bedřich Smetana and Karel Bendl. All three of them gave commendable marks to Gorenjski slavček and unanimously awarded it first prize. ${ }^{8}$ The evaluation committee assessed it as a "work freely written in a naively dilettantish style". ${ }^{9}$ The first to present his evaluation of Gorenjski slavček was Smetana, who on 20 January 1872 wrote, among other things, the following: "[...] the opera Gorenjski slavček without a doubt deserves the first and probably the only prize. It displays a fresh melody and imagination, rich harmonies and skilful instrumentation". ${ }^{10}$ Another member of the evaluation committee, composer and conductor Karel Bendl, wrote in his report on 24 January 1872 that the operetta Gorenjski slavček, which meets both aesthetic and musical criteria, is entitled to the first prize. ${ }^{11}$ This was further supported by music critic and editor Ljudevit Procházka, who expressed the opinion that

\footnotetext{
${ }^{5}$ Laibacher Zeitung, 29 April 1872.

${ }^{6}$ A report reveals that Foerster wrote the operetta in the years 1870-71. Trstenjak, Slovensko gledališče, 58 .

${ }^{7}$ Besides the above-mentioned two compositions, eleven more theatre works were entered in the competition. Among them were tragedies, dramas, and even comedies.

${ }^{8}$ Hribar's work Prepir o ženitvi (Quarrel about Marriage) supposedly did not meet the content requirements of the public competition. The reasons given were that it was written as a play with singing and not as an operetta, and that the composer did not submit the score, but only a piano excerpt.

${ }^{9}$ A transcript of the evaluation committee's original document can be found in the legacy of France Mohorič. Glasbena zbirka NUK, France Mohorič, Kronika.

${ }^{10}$ Ibid.

${ }^{11}$ Ibid.
} 
Weiss, J.: Anton Foerster's Gorenjski slavček: Slovenia's first national opera?

judging from the artistic and musical perspectives, there is no doubt that Gorenjski slavček is an absolutely successful creation written by a well-versed pen. Even from the absolute standpoint, it deserves undivided praise for its idea and form, naturalness and warmth. The renowned Provincial Committee will by all means grant first prize to this work, all the more so because its composer gave careful consideration to national particularities as well as practical execution. ${ }^{12}$

Based on the mentioned recommendations, on 8 March 1872 the Carniolan Provincial Committee awarded the first prize to Foerster and to the author of the libretto. The composer received 250 florins, and the librettist 75 florins. $^{13}$

One of the major Slovenian dailies, Novice (News), was the first to announce on 24 April 1872, the staging of Gorenjski slavček:

We can already see today how everything will be bubbling with activity at the theatre on Saturday, when the eagerly awaited national operetta Gorenjski slavček is performed for the first time to benefit the poor in Dolenjska and Notranjska. The charity performance will begin with a prologue written by Mrs. Lujiza Pesjak and recited by Miss Podkrajšek, and finish with the productions of our Sokol Society. ${ }^{14}$

The proceeds from the performance went to benefit the homeless in the Dolenjska and Notranjska regions. The leading German daily of that time, Laibacher Zeitung (Ljubljana Newspaper), also wrote about the upcoming première, and even announced it twice - on the 25 and 27 April, 1872. The newspaper reported that the Slovenian stage would perform "the national operetta Gorenjski slavček, whose name in German was Oberkrainer Nachtigall'. ${ }^{15}$ An unsigned reporter wrote that the operetta would be performed in Carniola for the first time: "The performance will begin with a prologue by Lujiza Pesjak, and finish with a production by the Slovenian Athletic Society, Sokol". ${ }^{16}$ All of this was, in the reporter's opinion, sufficient reason for as many people as possible to attend the performance. In its second report, the newspaper published the same text, and added that Lujiza Pesjak's prologue would be recited by Miss Podkrajšek and that "the choir of the Dramatic Society and the Reading Society will participate in the rendition of Gorenjski slavček. The operetta will also be performed for all external theatre visitors on the next day following the première, that is, on 28 April 1872". ${ }^{17}$

\footnotetext{
${ }^{12}$ Ibid.

13 The composer of the singspiel Prepir o ženitvi (Quarrel about Marriage), Anton Hribar, received a consolation prize in the amount of 80 florins.

${ }^{14}$ Novice, 24 April 1872.

${ }^{15}$ Laibacher Zeitung, 25 April 1872.

${ }^{16}$ Ibid.

${ }^{17}$ Laibacher Zeitung, 27 April 1872.
} 
The operetta was first performed under the composer's direction on 27 April $1872,{ }^{18}$ and was warmly received by the public. Its stage director was the then secretary of the Dramatic Society and one of the first important Slovenian theatre personalities, Josip Nolli, who also appeared at the première in the role of Chansonette. This was one of Nolli's first solo performances. In later years, Nolli enjoyed a European reputation as a baritone, making guest appearances on some of the leading European opera stages in the period from 1875 to 1890. Alongside him, the leading roles were performed by a number of less known Slovenian soloists: Antonija Svetek (Minka), Ivan Meden (Franjo), and Cecilija Podkrajšek - Rossa (Majda). ${ }^{19}$

The première of Slavček was highly praised in the reviews by the critics, as well. After the performance, politician and patriot Ivan Murnik wrote the following in Novice: "The operetta was - and rightly so - received with enthusiasm". ${ }^{20}$ He went on to report on the full house and praised the "simplicity" of the libretto and the composer, whose work was said to be truly exceptional. Murnik did not spare any praise for the performers, mentioning only that they had been inaccurate in some places. ${ }^{21}$ However, since he was the president of the Dramatic Society at that time, Murnik could not have been entirely objective in his evaluations. For this reason some other reports appear to be more relevant, among them a review published in the first Slovenian daily, Slovenski narod (Slovenian Nation). In this newspaper an unsigned critic reported on the immense enthusiasm which the performance had aroused among the audience. ${ }^{22} \mathrm{He}$ first commended the fact that the performance had been sold out. Even from the "musical perspective, the operetta had been brilliant. It revealed powerful instrumentation, showing that Anton Foerster was a masterful composer. The music itself had been complexly written for both instrumentalists as well as soloists and choir". ${ }^{23}$ Particularly interesting was the part about "powerful instrumentation", which, more than to the actual situation, pointed to the rarity and simplicity of some other instrumental compositions in Slovenia in that time. Namely, vocal ensembles were still predominant among Slovenian works in the second half of the $19^{\text {th }}$ century, and so creators consequently wrote mostly vocal compositions. Interestingly, the Slov-

\footnotetext{
${ }^{18}$ Dušan Moravec (ed.), Repertoar slovenskih gledališč 1867-1967, Ljubljana, Slovenski gledališki muzej, 1967, 176.

${ }^{19}$ Ibid. The first was a seamstress by profession, while the last two had a little more performing experience in different musical-stage roles.

${ }^{20}$ Novice, $1^{\text {st }}$ May 1872.

${ }^{21}$ Ibid.

22 Slovenski narod, 30 April 1872.

${ }^{23}$ Ibid.
} 
enski narod critic also praised the libretto, saying that it was "based on a simple, folk story". ${ }^{24}$ The article mentioned the repeat performance as well, which was staged the next day, though it was seen by a smaller number of spectators than the previous day. According to the critic, this was due to the nice weather. Another report was subsequently published in the Laibacher Zeitung, stating that Slovenians did not take an interest in their theatre and that Slavček lacked a quality libretto, but above all it lauded the musical side of the operetta. ${ }^{25}$

In any case, first of all, the operetta was a fortunate and not too demanding expression of Foerster's initial creativity, one of the rare operettas in Slovenia that paved the way for further Slovenian musical-stage productions. Despite its initial success, however, the operetta did not remain on the repertoire of the Dramatic Society. After 1872, it was almost entirely forgotten for more than two decades. This attitude, or rather, non-attitude, can primarily be attributed to pauses in the work of the Dramatic Society. Nor should one, in this respect, neglect the financial crisis that spread throughout the entire Austro-Hungarian Monarchy in 1873, mostly affecting smaller theatres in the Austrian provinces, including Ljubljana. The Dramatic Society did not begin to revitalise its activites until after 1886, when Fran Gerbič became its conductor. It was only then that some of the main features of the Dramatic Society's programmes could be compared to the programmes of the German Provincial Theatre, which operated in Slovenia unterruptedly until the beginning of the First World War.

\section{Gorenjski slavček - the opera}

The staging of Gorenjski slavček, consequently, was not on the agenda again until the early 1890's. Its première having revealed that Slavček's musical concept transcended the frames of an operetta and that its principal weakness was a naive libretto, the composer engaged Smetana's librettist from Prague, Emanuel Züngl, to rework the libretto, while Foerster himself composed some additional music pieces. It was Züngl's social stance regarding patriotism, which he had expressed in his texts for Smetana, that prompted the desire in Foerster to have him remake the libretto. He composed most of the spoken text in recitatives, but approximately one third of the libretto was still in prose. The Slovenian poet Engelbert Gangl helped him set this part to music.

It was not until the opening of the new Slovenian Provincial Theatre in 1892 that more opportunities emerged for staging Slovenian musical works.

\footnotetext{
${ }^{24}$ Ibid.

${ }^{25}$ Particularly the "mutual interweaving of Slavic and Italian motifs". Laibacher Zeitung, 29 April 1872.
} 
through its premières of Slovenian works, such as the opera Teharski plemiči (The Noblemen of Teharje) by Benjamin Ipavec (10 December 1892), ${ }^{26}$ this theatre specifically encouraged domestic musical-stage creativity. And so it was not long before the remake of Gorenjski slavček saw its first staging. On 30 October 1896, the newly arranged Slavček was "revived" on stage within the scope of a grand social event. The opera's première was conducted by the outstanding Czech conductor Hilarion (Hilarij) Benišek, who was also active in Belgrade in the period between 1910 and 1914 as a conductor of various salon orchestras and as a music teacher, ${ }^{27}$ and directed by Josip Nolli. The latter had already directed the first staging of the operetta.

Initially, the opera was peformed in two acts. But, by the next performance on 3 November 1896, Foerster had divided the first act into two parts and slightly shortened the second act, as instructed by critics. And so Gorenjski slavček became a three-act opera. The public was enthusiastic about the opera's rearrangement, which featured some newly added traditional Slovenian folk melodies. The theatre management popularised the opera with a special performance at lower prices. This attempt was successful, and the opera's third performance on 7 November 1896 was almost entirely sold out. The opera's fourth and last performance in its first season was staged on 13 December 1896.

On 12 November 1896, an unsigned critic wrote in Slovenski narod (Slovenian Nation) the following:

Several national costume societies from Radovljica, Bled, Brezovica and other places in the Gorenjska region have requested that the Dramatic Society organise, at the beginning of the upcoming month, a performance of Foerster's original opera Gorenjski slavček, with special regard to guests from Gorenjska, who intend to attend the performance in Ljubljana in a large number. ${ }^{28}$

And so a special "Gorenjska train" arrived in Ljubljana with more than 150 visitors from Kranjska Gora, Dovje and Mojstrana, Zabreznica, Jesenice, Radovljica, Bled, Podnart, Kranj, Kropa, Kamna Gorica, Kamnik, etc. Among them were both intellectuals and farmers, some were even wearing national costumes. The theatre was once again completely sold out, and there was great en-

\footnotetext{
${ }^{26}$ Igor Grdina, Ipavci: zgodovina slovenske meščanske dinastije, Ljubljana, Založba ZRC SAZU, 2001, 267-285.

27 Jernej Weiss, Hilarion Beníšek (1863-1919) and other Czech conductors at the Slovenian Provincial Theatre at the turn of the $20^{\text {th }}$ century, in: Katarina Tomašević (ed.), Zbornik Matice srbske, Belgrade, Matica srbska, 2014.

${ }^{28}$ Slovenski narod, 12 November 1896.
} 
Weiss, J.: Anton Foerster's Gorenjski slavček: Slovenia's first national opera?

thusiasm among the audience. ${ }^{29}$ Even Laibacher Zeitung, which had always been extremely critical towards Slovenian musical-stage creativity, greeted Slavček after its first remake into an opera with approval. On 3 November 1896, poet and translator Anton Funtek wrote the following in this newspaper: "On Friday Gorenjski slavček was staged for the first time in its new form as a comical opera and, as could be expected, was welcomed with enthusiasm. The audience has had its say, and the critics can do nothing to change that. Success has come, and it is here to stay even after the repeat performances. Foerster's work is a musical work of art, and we can certainly be proud of this new Slovenian opera" ${ }^{30}$ However, in his review, Funtek also drew attention to certain deficiencies, such as, for example, the fact that the comical opera Gorenjski slavček ends with a lyrical chorus of Ave Maria, which is not considered suitable for this type of lighter musical genre. ${ }^{31}$ Similar views on the new Slovenian opera were also expressed in other Slovenian newspapers and periodicals. For example, Ljubljanski zvon (The Ljubljana Bell) published, in its December 1896 issue, a review by the deeply insightful Czech critic, pianist and composer Karl Hoffmeister:

$[\ldots]$ The composer of Gorenjski slavček is undoubtedly conscious of the fact that he has not written a new Magic Flute or Marriage of Figaro. Yet he has written a pretty good opera [...]. If there is any deficiency to be found in the opera, it is perhaps the modest action: an innocent, poorly dramatic idyll to which the master of theatrical routine, Züngl, attempted to add precisely what was lacking on stage - that is, lively examples that can be used in a composition. But if the composer understood the composition in such a way that this deficiency could not be felt for the entire evening, he is certainly worthy of the greatest recognition $[\ldots]$. There are usually very few gigantic pyramids in the history of the young art of young nations. Yet Foerster has erected an honorary obelisk in the history of Slovenian music which the sands of time will not bury so soon. ${ }^{32}$

Hoffmeister's evaluation seems to reflect quite a realistic view of Foerster's rearrangement of Gorenjski slavček. All renditions of Slavček in 1896 were conducted by Hilarion Benišek, a young Czech who had come to the Ljubljana Theatre the year before, and successfully directed it in the years that followed.

\section{Slovenia's first national opera?}

Some comparisons of Foerster's opera with Smetana's Bartered Bride appeared in daily newspapers, particularly after its successful première. Smetana's

\footnotetext{
${ }^{29}$ Ibid.

${ }^{30}$ Laibacher Zeitung, 3 November 1896.

${ }^{31}$ Ibid.

${ }^{32}$ Ljubljanski zvon, 2 December 1896.
} 
opera had become quite well-known in Slovenia following its world première at the Prague Provisional Theatre on 30 May 1866. Less than two years after the première, on 3 May 1868, a music piece from the beginning of the first act of Smetana's opera, sung by a choir of villagers, was performed at a social event organised by the Ljubljana Reading Society at the Provincial Theatre in Ljubljana. ${ }^{33}$ Primož Kuret was among the first to write that the Ljubljana Reading Society choir, which then comprised "50 male and 20 female singers" 34 , and the military band of Count Huyn's infantry regiment had been conducted by Anton Foerster himself. ${ }^{35}$ Novice reported that this musical performance had been wellreceived by the audience. ${ }^{36}$ Since Fran Gerbič also performed at this concert, it is not hard to guess how the score of Smetana's second opera had come into Foerster's hands.$^{37}$ Namely, during his studies in Prague, Gerbič had been among the first Slovenians to become acquainted with The Bartered Bride ${ }^{38}$ Although Foerster had already been in Senj (Croatia) at the time when The Bartered Bride was written, and the opera was not staged in its entirety in Slovenia until 1894, ${ }^{39}$ he seems to have been well-acquainted with it before writing his operetta. There appear to have been certain speculations ${ }^{40}$ as to when Foerster had become familiar with The Bartered Bride. After all, as early as in the second half of the 1860 's, reports about the opera could be found in numerous Czech newspapers that were regularly subscribed to by the National Reading Society in Ljubljana. The members of the Reading Society were thus able to follow the activities of Bedřich Smetana from various reports published in Czech newspapers. It seems probable that Lujiza Pesjak had also been acquainted with the above-mentioned Czech national opera at the time when the libretto of Gorenjski slavček was written, as there are indisputable parallels between the two operas as regards their

\footnotetext{
${ }^{33}$ Novice, 4 May 1868.

${ }^{34}$ Ibid.

${ }^{35}$ Primož Kuret, Ljubljanska filharmonična družba: 1794-1919: kronika ljubljanskega glasbenega življenja v stoletju meščanov in revolucij, Ljubljana, Nova revija, 2005, 166.

${ }^{36}$ Novice, 4 Maj 1868.

37 The music for this opera was printed in large editions. The Slovenians contented themselves with German editions, in which they entered Slovenian translations.

${ }^{38}$ In the fall of 1864 , Gerbič went to study in Prague, where he met Bedřich Smetana and, two years later, became acquainted with his opera, The Bartered Bride.

${ }^{39}$ The performance was conducted by Fran Gerbič, and directed by the famous director of Gorenjski slavček, Josip Nolli. Moravec (ed.), Repertoar slovenskih gledališč 1867-1967, 181.

${ }^{40}$ Kristijan Ukmar, „Zgodba Gorenjskega slavčka”, Gledališki list SNG Opere in baleta Ljubljana, 2013, 15.
} 
Weiss, J.: Anton Foerster's Gorenjski slavček: Slovenia's first national opera?

characters (particularly the love triangles between Jeník-Mařenka-Kecal and Franjo-Minka-Chansonette) and the prevailing social theme. Smetana's opera had also undergone a similar fate in its development as Foerster's did later on; at its first staging in 1866, The Bartered Bride had only two acts with an overture, 20 music pieces and a spoken dialogue. It was not until four years later that the composer added a number of new music pieces and five recitatives, and divided the opera into three acts.

However, these were more or less superficial comparisons which, more than Foerster's creative endeavours, revealed the aspirations of reporters and the opera management to proclaim Foerster's Gorenjski slavček a national opera, following the example of Smetana's Bartered Bride. Namely, there are also considerable differences between the two operas from the musical perspective. Foerster very openly quoted certain Slovenian folk or popular melodies in his opera, while Smetana only occasionally used folk motifs. This raises the question of the national authenticity of Foerster's opera, which cannot be attained merely by reaching into folk tradition, as Smetana himself had discovered. This is because the folk songs that have been preserved in one language contain not only national, but also local, regional and international particularities.

It seems that certain relevant differences in content between the two operas can also be observed in the libretto. ${ }^{41}$ Contrary to Smetana's opera, the central focus of the action in Gorenjski slavček is on the division between homeland and a foreign country. Given the ongoing wave of emigration due to social necessity and the burning issues involving the search for identity, Foerster's work seems more realistic. The social reality of illusions abroad and the longing to re-

\footnotetext{
${ }^{41}$ The main scene of Smetana's comical opera is a typical Czech village and its inhabitants, simple farmers. Lovely Mařenka, daughter of a wealthy large landowner, fit for marriage, has already chosen her husband-to-be, Jeník, who is as poor as a church mouse. For this reason, her father promises her to the son of a rich fellow villager. But Jeník is no loser. By trickery, he manages to outsmart the matchmaker, the broker Kecal, so that his chosen bride finds herself marrying him in the end. Owing to its humorous scenes and music written in a Czech national tone, the opera won the hearts of Czech audiences, and became popular in other countries, as well.

The libretto of Gorenjski slavček tells the story of Franjo, who returns to his home village, where he is eagerly awaited by his friend Lovro, as well as his girlfriend Minka. Passing through this idyllic village of Gorenjska at this time is the mocking Chansonette, who hears Minka sing and instantly decides to take the young girl out into the world so that she can train her voice and earn a living by singing. All of this happens at a time when Minka's family is being driven from its home by creditors. Although Chansonette offers money, the villagers decide to prevent the intruder from carrying out his plans. In the end, Minka remains with her Franjo in Gorenjska, while Chansonette and his wife return to their homeland.
} 
turn home were becoming increasingly more topical at that time. ${ }^{42}$ The triangle home-poverty abroad-return is a kind of archetype that cannot be perceived in Smetana's operas. Vladimir Karbusicky found that the choice of libretto reflects the social components of the origin of one and the other composer: Smetana came from a wealthy environment, while Foerster was born into a family of teachers and cantors with deep-rooted "folklore" elements, which was directly connected to folk life from the $18^{\text {th }}$ century onward. ${ }^{43}$

Given the above-mentioned background, one could hardly agree with the opinion of opera anthropology researcher Vlado Kotnik, who, in his sociologically based study, wrote that some Slovenian music creators and their musicalstage works prepared the way for Slovenian opera, which, with the staging of Foerster's Gorenjski slavček, "finally culminated in the image of the first recognisable Slovenian national opera" ${ }^{44}$ Considering its immanent musical charactristics, Foerster's work seems more like a warm and rather undemanding expression of intimacy than a national opera in the true sense of the word. And this in spite of the fact that he had gradually begun to transform Slavček into an opera as early as in 1876, when he rearranged his score, it seems, for the first time. ${ }^{45}$ Jože Sivec rightfully wrote:

The life force of Gorenjski slavček is undoubtedly in its simple warmth, naive easiness, and in its connectedness with the domestic soil, its people and their customs. Although this piece of idyllic Slovenian life in Gorenjska, set within the simple form of this opera, does not represent a synthesis of our essentiality in an entirely purified and artistically established expression, it is nevertheless portrayed so pleasingly that its cheerfulness and refreshing easiness has touched our people again and again. ${ }^{46}$

In the opera Foerster masterfully characterised the natures of individual persons. In spite of this, however, in some places the naive libretto did not allow

\footnotetext{
${ }^{42}$ Especially for numerous Czech musicians and other migrants. The wave of emigration of poor people that swept across the Czech lands, particularly in the second half of the $19^{\text {th }}$ century, represented a true demographic catastrophe for the Czechs. Equally unfavourable were the consequences of the emigation of Slovenians to America in that period.

${ }^{43}$ Karbusicky, „Gorenjski slavček - Prepad med domovino in tujino“, 102.

${ }^{44}$ Vlado Kotnik, Antropologija opere: Pomen idej o operi za razumevanje opernega fenomena in imaginarija, Koper, Univerza na Primorskem, Znanstveno-raziskovalno središče, Zgodovinsko središče za južno Primorsko, 2005, 72.

${ }^{45}$ An incomplete score dated $1^{\text {st }}$ January 1876 has been preserved in Foerster's legacy in the Musical Collection kept at the National University Library (NUK). However, only 90 pages of the score are preserved in their entirety.

46 Jože Sivec, „Foersterjev Gorenjski slavček”, Gledališki list SNG Opere in baleta Ljubljana, 1972.
} 
Weiss, J.: Anton Foerster's Gorenjski slavček: Slovenia s first national opera?

him any more dramaturgical expansion. This was the greatest stumbling-block already in the first performances of both the operetta and the opera. The deficiencies in the libretto led to numerous subsequent corrections of the text, as well as replacements and additions of scenes. The individual acts of the opera seem like almost overly composite units, resulting in a visible loss of character in some places, and the opera as a whole consequently losing its cohesion. These pieces are mostly conceived as choral compositions set to music, as the orchestra generally only accompanies the singing performances and rarely resorts to tone painting, which is, for example, one of the main characteristics of Smetana's Bartered Bride.

The fact that the opera's roots are in the operetta can therefore be recognised in its subsequent remakes, as it does not contain any typical operatic characteristics. The soloist melodies in the individual acts pass from one into the other. Yet in the creative circumstances existing in Slovenia at the time, Foerster nevertheless demonstrated an enviable compositional-technical level in Gorenjski slavček.$^{47}$ The reasons for the opera's resounding success in the 1890's lie, alongside its rearrangement, primarily in the changed social and political circumstances, which were more strongly inclined towards the demonstration of patriotic feelings in the period discussed. After its première, the composer left the opera Gorenjski slavček in the hands of the Dramatic Society for a period of five years, which considerably helped both the said institution and the composer to improve their financial positions. ${ }^{48}$ Soon afterwards, however, the political and social role of the opera in German, and later also in certain Slovenian daily newspapers led to growing criticism regarding the inadequacy and deficiency of its libretto. ${ }^{49}$ Precisely this type of criticism, which mostly used the opera's libretto as a pretext, deterred endeavours to restage the opera in the first decade of the $20^{\text {th }}$ century. ${ }^{50}$

\footnotetext{
${ }^{47}$ Borut Smrekar, „Foersterjevi operi“, in: Edo Škulj (ed.), Foersterjev zbornik, Ljubljana, Družina, 1998, 97.

${ }^{48}$ The contract is preserved in the legacy of Fran Mohorič. Mohorič, Kronika.

${ }^{49}$ The criticism intensified after the so-called ,separation of spirits". Particularly in the early $20^{\text {th }}$ century, there appeared in the Slovenian lands a number of more radical ideas which opposed the ,invasion” of German and also Czech culture in Slovenia. This opposition was not directed so much against the Czechs as against the prevailing, more liberal political option represented by young Czechs, which was not well-received, particularly in Slovenian conservative circles.

${ }^{50}$ Janko Traven, ,Vprašanje izvirnega slovenskega opernega besedila”, Gledališki list SNG Opere in baleta Ljubljana, 1953, 6.
} 


\section{Numerous remakes of Gorenjski slavček}

Despite its enormous success in 1896, the opera was not restaged until 1922. Even four performances of Gorenjski slavček in Brno in $1910^{51}$ did not arouse any greater interest in its restaging. It is interesting that, during later performances of the opera, Foerster supposedly planned the revision of the libretto with Czech librettist Jindřich Böhm, but this was never realised. In 1902, Foerster also offered Gorenjski slavček to a theatre in Nürnberg and another in Berlin, but the opera was never staged there. ${ }^{52}$

On the initiative of Matej Hubad, renewed endeavours to stage Gorenjski slavček began in $1922 .{ }^{53}$ Hubad had been inspired by the composer's $85^{\text {th }}$ birthday, which corresponded with the $50^{\text {th }}$ anniversary of Ljubljana's Music Society. Conductor Karel Jeraj and director Osip Šest agreed that the opera in its current form still had some shortcomings, and so they remade both its music and contents. ${ }^{54}$ In doing so, the authors strove to remain true to Foerster's original opera. They retained the division of the opera into three acts, but added some new texts to individual scenes, deleted less successful parts of the score, and rearranged their sequence. Minka's original aria, in which she charms Chansonette, was replaced with a Slovenian folk song, Goreči ogenj brez plamena (Burning fire without a flame); another folk song, Vsi so prihajali (All were coming) was added to the ensemble scene at the end of the second act as Minka's and Franjo's concluding duet; the beautiful mixed chorus of Ave Maria, which had previously represented the opera's conclusion, was placed at the beginning of the third act. Jeraj also corrected the instrumentation in some places, the most noticeable change being the addition of a harp to the orchestra. From them, onward, the opera ended with a medley of Slovenian folk songs, which was certainly a most appropriate and effective conclusion for an otherwise comical opera. Slavček was staged with resounding success on 30 November 1922. By that period, the opera had been performed more than 40 times in this modified version, which has more or less been preserved to the present day.

Critics welcomed the last remake of Gorenjski slavček with enthusiasm. France Kimovec wrote in Slovenec (The Slovenian): "[...] a magnificent resurrection, like a reborn phoenix rising. This kind of success has never been

\footnotetext{
${ }^{51} 1^{\text {st }}, 2^{\text {nd }}, 7^{\text {th }}$ and $12^{\text {th }}$ January 1910.

${ }^{52}$ From the legacy of Fran Mohorič. Mohorič, Kronika.

${ }^{53}$ Hubad became director of the National Theaatre in Ljubljana in 1922. The director of the Opera House in that period was Friderik Rukavina.

${ }^{54}$ Given the previously mentioned homage to the composer on his $85^{\text {th }}$ birthday, the author appears to have agreed with the remake.
} 
Weiss, J.: Anton Foerster's Gorenjski slavček: Slovenia's first national opera?

achieved by any opera at our theatre $[\ldots]$ ". ${ }^{55}$ This led to the reappearance of commentaries that Foerster had been guided in his composing by the desire to create Slovenia's first national opera. ${ }^{56}$ Yet it seems that the composer's real intention was primarily to write a stage music composition that would appeal to and be easily understood by the ordinary public, an opera that would first of all respond to the topical social issues of the day. Using the simple rural theme of the libretto by Lujiza Pesjak and Emanuel Züngl that portrays the infinite beauty of the Gorenjska countryside and the honesty of its women and men, seasoned with a romantic and patriotic plot between Minka, Franjo and a Frenchman, Chansonette, the composer managed above all to bring this three-act opera closer to the simple, rural man. By including a number of national folk melodies in particular, he managed to instill feelings of hope in the rural population alongside the worries that tormented them due to the growing wave of emigration triggered by all the more pressing social issues, and finally awakened their national consciousness. This mixture of romantic and patriotic themes, which has been a formula for success since time immemorial, managed to attract broad masses of the public to the theatre. And so the opera with its popular melodies known to all, such as Že priletela ptičica; Sijaj, sijaj sončece; Al me, al me boš kej rada imela, etc., has continued to attract interest, which is also evident in its subsequent remakes.

Amont these was a very extensive, but not too successful rearrangement made by conductor Mirko Polič and dramatist Josip Vidmar for the opera's rendition on 20 November 1937 . The two of them prepared a considerably modified version of the opera, which differed noticeably from the original work both in its content and musical image. The plot was transposed to the period of Napoleon's conquests: the castle keeper Štukelj stalks Minka, but her singing also attracts the attention of the French captain Champigny; Janko, Minka's sweetheart, is a soldier in the Austrian army, and so Champigny invites Minka into the big broad world, but in the end she chooses to remain with her Janko; the news that Napoleon has announced the establishment of the Illyrian Provinces is met with jubilation. The remade libretto had an extremely patriotic note that reflected the changing social and political circumstances after the end of the First World War. Although the musical material was still Foerster's, its preparation, execution and instrumentation were done by Polič. The opera thus acquired an entirely new tone, as well as a new technical execution. ${ }^{57}$ But Polič's remake was nowhere

55 Slovenec, 1922, No. 266, 6.

${ }^{56}$ Dom in svet, 1922, No. 2, 570.

${ }^{57}$ Henrik Neubauer, Vodnik po operah slovenskih skladateljev and Matija Bravničar, Anton Foerster: Gorenjski slavček, Gledališki list SNG Opere in baleta Ljubljana, 2000. 
near as successful as Jeraj's rearrangement fifteen years beforehand. According to the critics, the most negative aspect of the remake was that Polič did not remain true to Foerster's original opera either in the musical sense or in its content, and in this way partly erased the opera's character. ${ }^{58}$ Polič's version was consequently soon forgotten and the majority of the opera's subsequent stagings were based on the 1922 version, ${ }^{59}$ to which conductor Rado Simoniti added a folk song, Potrkan ples ${ }^{60}$, in his instrumentation for its rendition on 27 May 1953.

It is, however, true that almost all the conductors and directors of Slavček made some additions, deletions or changes in every new staging of the opera. Because the original score was long considered to be lost, conductors in both Ljubljana and Maribor always conducted the performance from a remade, crossed out, supplemented, and glued together (at the end literally falling apart) piano excerpt based on a printed issue of the Ljubljana Music Society dating from 1901. ${ }^{61}$ It was only when conductor Lovrenc Arnič and director Henrik Neubauer were preparing a staging of the opera on 4 October 1984 that, shortly before the première, a photocopy of the manuscript of the opera's original score was found in one of the archival depots at the institution. The copy also contained a stamp with the inscription Ljudska republika Slovenija, Slovensko narodno gledališče v Ljubljani (Peoples' Republic of Slovenia, Slovenian National Theatre in Ljubljana) and the national coat-of-arms. The copy had therefore been made approximately twenty years after the Second World War, ${ }^{62}$ which means that Foerster's original score had been available to performers then, as well. ${ }^{63}$

This photocopy nevertheless brought some progress, even though its dramaturgy differed from that of the original opera, but was closest to the 1922 version, which means that it, too, had been considerably shortened and certain parts deleted. Due to time pressures in 1984, it was not possible to write new orchestra material, and so the old material was adapted (again by gluing, correcting, rear-

\footnotetext{
${ }^{58}$ Slovenec, 1937, Nos. 2, 13; See also: Slovenski narod, 1937, No. 267, 8.

${ }^{59}$ Jeraj's remake of Slavček could be heard in the 1939/40, 1943/44 and 1952/53 seasons, and Polič's only in the 1937/38 season.

${ }^{60}$ According to Borut Smrekar, this has remained questionable both in the dramaturgical and musical sense. Smrekar, „Foersterjevi operi“, 96.

${ }^{61}$ In 1901, the Music Society in Ljubljana issued a piano excerpt of the opera with Slovenian and German texts, and gave it to its members as a gift. The excerpt was published by a Vienna publishing house, Josip Eberle \& Co.

${ }^{62}$ In all probability it dates from 1967, on the hundredth anniverssary of the Dramatic Society in Ljubljana. See the photocopy of the original score's manuscript in the archives of the Slovenian National Theatre Opera and Ballet Ljubljana.

${ }^{63}$ The composer's score dating from 1896 is today kept in the archives of the Society of Slovene Composers.
} 
ranging, and adding music) to the original instrumentation. Although Neubauer and Arnič did their best to bring the contents closer to the original piano excerpt, this could not be done because of the shortened score in the photocopy. From the subsequently added pieces, they excluded Potrkan ples, retained Goreči ogenj and Vsi so prihajali, and replaced the Ave Maria at the end of the opera with a repetition of the introductory choral song Gorenjci. Pavel Oblak revised some of the most outdated parts of the text. ${ }^{64}$

The situation called for new music material. After deciding to stage a new performance, which happened on 12 December 1996, the then director of the Slovenian National Theatre Opera and Ballet Ljubljana, Darijan Božič, realised the idea of renewing the music material. The music engraving and printing in their own publishing house, Vivo, was entrusted to Czech director František Preisler. Božič rearranged the contents of the material and chose Simoniti's version dating from 1953, which, in his opinion, had been the most successful one. For computer processing of the music material, Preisler used several piano excerpts, some orchestra materials and, of course, the photocopy of the original score. ${ }^{65}$

The last première of Gorenjski slavček was staged on 13 March 2013. Conductor Igor Švara and director Vito Taufer endeavoured to follow Foerster's original opera as closely as possible. This was "Švara-Taufer's" version, in which the two of them sought a dramaturgical thread in the sense of autochthonous content, and cleansed Slavček of certain additional "non-Foerster" pieces. An important novelty of this performance was that Taufer was the first to reinterpret Slavček using a modern directorial approach. Yet, his Disney-inspired production seems like a deconstruction only at a first glance. In this version, Gorenjski slavček is no longer merely a patriotic, sentimental picture of Sloveneness, but in Taufer's directorial setup it tends towards the darker, intolerant (Minka as the victim of male chauvinism and society) and self-sufficient side of the national idyll. The opera thus continues to raise topical issues, and despite the non-existence of an integral, musicologically commented edition that would be necessary for a more detailed insight into the picture of the subject matter, it offers opportunities for further original performance. After all, the opera is by far the most popular Slovenian musical-stage production that has been performed more than 100 times in Ljubljana's theatre alone; next, is Victor Parma's Ksenija with slightly less than 30 stagings. ${ }^{66}$

\footnotetext{
${ }^{64}$ Henrik Neubauer, „Ob novi premieri Gorenjskega slavčka”, and Lovrenc Arnič, „Gorenjski slavček in nova redakcija”, Gledališki list SNG Opere in baleta Ljubljana, 1984.

65 Darijan Božič, „Moja tri srečanja z Gorenjskim slavčkom”, and František Preisler, „Končno oder!”, Gledališki list SNG Opere in baleta Ljubljana, 1996.

${ }^{66}$ Moravec (ed.), Repertoar slovenskih gledališč 1867-1967.
} 
A great deal less successful in this respect was Foerster's second opera, entitled Dom in rod (Home and Family). Despite having gone into retirement in 1909, Foerster did not abandon his creative work. He continued to compose music and took an interest in the development of musical life in Slovenia. During the First World War, he moved to Novo mesto in 1917 to live with his son Vladimir, and primarily devoted himself to collecting and arranging his works. It was there that he finished in 1923 his second, still unstaged opera Dom in rod. ${ }^{67}$ Foerster did send the opera to the National Theatre in Ljubljana, and it was included in the repertoire of the 1923/24 season. ${ }^{68}$ However, the opera was never staged. The management returned the work to the composer without giving any justified reason, as if to say that it could not stage the opera. Most likely, the greatest flaw in this work was the poor quality of its libretto, which, as Borut Smrekar wrote, was a kind of "collage of songs and monologues". ${ }^{69}$ As such, it appeared extremely naive, which, considering the place, environment and social classes in which the story unfolds, was quite disturbing.

Therefore, particularly at the end of the $19^{\text {th }}$ century, the constantly rising Slovenian national consciousness saw a great opportunity in theatre and opera, which became the center of a national movement with which the young bourgeoisie identified itself. The Ljubljana Reading Society had already begun to reintroduce stage music productions, by including music pieces in drama performances. Its work was then continued by the Dramatic Society and, from 1892 onward, by the new, first Slovenian Opera House. Foerster's Gorenjski slavček soon became the most popular and most frequently performed Slovenian musical-stage work. The attributes of "national opera" or "Slovenia's Bartered Bride", with which Foerster supposedly outlined the direction of Slovenian national opera music, were above all an expression of euphoria by the then extremely nationally-oriented publicists and the management of the Opera House. In addition, the fact that Foerster used a number of Slovenian national and popular melodies to achieve a domestic, Slovenian tone undoubtedly contributed to defining Gorenjski slavček as a national opera. The principal reason why the opera achieved such outstanding success in the 1890's was, besides its rearrangement, above

\footnotetext{
${ }^{67}$ Alongside the mentioned works, Foerster's musical theatre opus also included the youth singspiel Lejla and the singspiel Materin blagoslov (Mother's Blessing). The latter was staged by the Dramatic Society in 1876 and 1891, and later on Foerster used the music from this work in his opera Dom in rod. It took him three years to compose this work, whose score was completed in 1923 and comprises 527 pages. Jože Sivec, Opera skozi stoletja, Ljubljana, Državna založba Slovenije, 1976, 317.

${ }^{68}$ Jutro, 9 September 1923; See also: Slovenski narod, 16 September 1923.

${ }^{69}$ Smrekar, „Foersterjevi operi”, 98.
} 
Weiss, J.: Anton Foerster's Gorenjski slavček: Slovenia's first national opera?

all the changed social and political circumstances, which were more strongly inclined towards the demonstration of patriotic feelings in the period discussed. Consequently, Foerster's Gorenjski slavček was soon proclaimed to be the fundamental Slovenian musical-stage work of the $19^{\text {th }}$ century. Its warm reception led the Slovenian bourgeoisie in particular to believe that Slavček could become the first Slovenian national opera.

Considering the overall image of Foerster's Gorenjski slavček in music history and the social and political issues of the time in which it was written, the opera seems more like a pleasant and rather undemanding expression of intimacy than a national opera in the true sense of the word. For adequate aesthetic consideration, the opera should therefore be understood primarily as a document of its time and the circumstances of its origin, in all its simplicity and naivety. This is, after all, evident in the fact that all subsequent changes in the score were generally less favourably received by audiences and critics alike. Gorenjski slavček is, therefore, in the first place, one of the rare original Slovenian musical-stage works that were created as the product of truly honorary endeavours in the young Slovenian musical culture of that time for its very own Slovenian theatre creativity. Although from today's perspective, the opera does not attain an above-average level and as such would not be capable of achieving success on foreign opera stages, it is by all means an interesting achievement because of the very specific role it played as a highly important national agitator in the period discussed. 